$1-1-1923$

\title{
Certain Correlations in the Weight and Number of Eggs and the Weight of Fowls
}

Horace Atwood

Follow this and additional works at: https://researchrepository.wvu.edu/ wv_agricultural_and_forestry_experiment_station_bulletins

\section{Digital Commons Citation}

Atwood, Horace, "Certain Correlations in the Weight and Number of Eggs and the Weight of Fowls" (1923). West Virginia Agricultural and Forestry Experiment Station Bulletins. 182.

https://researchrepository.wvu.edu/wv_agricultural_and_forestry_experiment_station_bulletins/182 @ WVU. It has been accepted for inclusion in West Virginia Agricultural and Forestry Experiment Station Bulletins by an authorized administrator of The Research Repository @ WVU. For more information, please contact ian.harmon@mail.wvu.edu. 


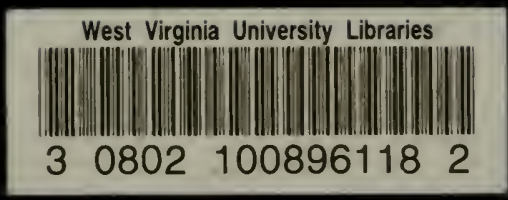


Digitized by the Internet Archive in 2010 with funding from

Lyrasis Members and Sloan Foundation 


\section{Agricultural Experiment Station}

College of Agriculture, đetest Viruinia annibrsity

IIENRY G. KNIGHT, Director

Morgantown

Certain Correlations in The Weight and Number of Eggs and The Weight of Fowls

('Ieclinienl)

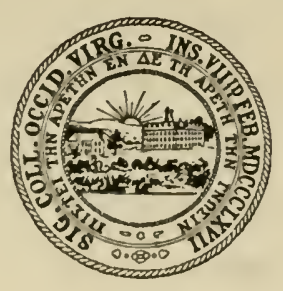

BY

IORACE ATWOOI) 


\section{AGRICULTURAL EXPERIMENT STATION STAFF}

FRANK B. TROTTER, A.M., LL.D.

President of the University

GEORGE R. LYMAN, Ph.D.

Dean of the College of Agriculture

HENRY G KNIGHT, Ph.D.

C. E. STOCKDALE, B.S. Agr.

JOHN C. JOHNSTON.

Director of the Experiment Station

\section{AGRONOMY}

R. J. Garber, Ph. D.

T. E. Odland, M. S. Assistant Agronomist

T. C. McIlvaine, M. S.

Assistant Agronomist

K. S. Quisenberry, B. S.

Assistant Agronomist

\section{ANIMAL HUSBANDRY}

E. A. Livesay, M. S.

E. C. Stillwell, M.S

Animal Husbandman

Assistant Animal Husbandman

Chas. V. Wilson, B. S. Agr.

Assistant Animal Husbandman

R. H. Tuckwiller, B. S. Agr.*

Assistant Animal Husbandman

\section{CHEMISTRY}

Henry G. Knight, Ph. D. Chemist

Chas. E. Weakley, Jr.

F. B. Kunst, B. A.**

Assistant Chemist

Assistant Chemist

T. B. Leith, B. A.** Assistant Chemist

T. J. Cochran, B. S.**

Assistant Chemist

\section{DAIRY HUSBANDRY}

Ernest L. Anthony, M. S. Agr.

Dairy Husbandman

H. O. Henderson, M. S. Agr.

Assistant Dairy Husbandman

Warren Gifford, B. S. Agr.

Assistant in Dairy Husbandry

\section{ENTOMOLOGY}

L. M. Peairs, M. S.

W. E. Rumsey, B. S.**

Entomologist

State Entomologist

FARM ECONOMICS

A. J. Dadisman, M. S. Agr.

J. H. Shaffer, B. S. Agr.

Farm Economist

Assistant Farm Economist

F. D. Cornell, B. S.

Assistant Farm Economist
Agricultural Editor Chief Clerk

HORTICULTURE

M. J. Dorsey, Ph. D.

Horticulturist

H. L. Crane, M. S. Agr.

Associate Horticulturist

H. E. Knowlton, Ph. D.

Associate Horticulturist

K. C. Westover, B. S. Agr.

Assistant Horticulturist

Ernest Angelo, B. S. Agr.

Assistant Horticulturist

L. F. Sutton, B. S. Agr. $\dagger$

Assistant Horticulturist

P. M. Daly, B. S.

Assistant in Horticulture

Troy M. Currence, B. S. Agr.

Assistant in Horticulture

PLANT PATHOLOGY

N. J. Giddings, Ph. D.

Anthony Berg, B. S.

Assistant Plant Pathologist

L. H. Leonian, $\mathrm{Ph} . \mathrm{D}$.

Assistant Plant Pathologist

E. C. Sherwood, M. S.

Assistant Plant Pathologist

POULTRY HUSBANDRY

Horace Atwood, M. S. Agr.

Poultry Husbandman

SOILS

E. P. Deatrick, Ph. D.

Associate Soil Technologist

O. C. Bryan, Ph. D.

Associate Soil Technologist

VETERINARY

C. A. Lueder, D. V. M. Veterinarian

*In Co-operation with the IT. S. Department of Agriculture, Washington, D. C. **In Co-operation with the State Department of Agriculture, Charleston, W. Va. tIn Co-operation with the Reymann Memorial Farms, Wardensville IV. Va.

In Charge of the Maggie Sub-Station, Maggie, W. Va, 


\section{Certain Correlations in the Weight and Number of Eggs and the Weight of Fowls}

It is well known that eggs differ in weight, and that even the eggs laid by the same hen are not all of the same weight. When a hen lays for several days in succession the first egg is usually the heaviest (1), and there is generally a fairly regular decrease in egg weight from day to day, the last egg in the cycle being the smallest (2). There is also a seasonal variation in the weight of eggs (3), the eggs being heaviest in the spring of the year and gradually becoming smaller toward the end of the laying season; scanty feeding and feeding an unbalanced ration also reduces the size of the eggs. Hadley and Caldwell (4) have studied the normal distribution of egg weight and have called attention to several interesting relationships. It is also known that the breeds of fowls differ with respect to the mean weight of their eggs; Minorcas, for example, laying very large eggs.

The food value of an egg depends upon its weight as well as upon its freshness, but as eggs are usually sold by count little attention has been given by investigators to the factors which bring about variations in weight. Egg weight is also of importance to the breeder of poultry as it has been shown (5) that heavy eggs hatch out heavy chicks.

\section{FOWLS USED IN THE EXPERIMENT}

The data discussed in this publication were obtained from six different flocks of Single Comb White Leghorns. These were designated as flocks A, B, C, D, E, and F. Each bird in Flock A had one or more full sisters in Flock $B$, and vice versa. The birds were hatched August 14, 1920. Likewise, the fowls in Flocks C and D were sisters. They were daughters of the birds in Flocks A and B, and were hatched July 24, 1921. The birds in Flocks $E$ and F also

(1) W: Va. Agr. lixp. Station Julletin 166.

(2) Me. Agr. Wxp. Station Bulletin 228 .

(3) W. Va. Agr. Exp. Station Bulletin 145.

(4) R. I. Agr. Fxp. Station Bulletin isi. 
were sisters, and they were the daughters of the birds in Flocks A, B, C, and D. These birds were hatched June 18, 1922. All of these birds were used in an experiment to study the influence of the ration fed to growing chickens upon the later characteristics of the females and reported upon elsewhere (6) (7).

The birds in Flocks $\mathrm{A}, \mathrm{C}$, and $\mathrm{E}$ were fed well while young, $A$ and $C$ receiving an abundance of sour skimmed milk and a moderate amount of meat scrap during chickhood, while the protein of animal origin supplied to Flock E consisted of whole milk fed sour. Flocks B, $D$, and $F$ were fed rations similar to those supplied to $A, C$, and $E$, respectively, except that the amount of milk was greatly restricted causing these birds to be of slow growth while young.

After the first egg was laid by the most precocious pullet, the birds in Flocks A and B were placed together and a trap nest record was kept of each bird. The following year the birds in Flocks C and $\mathrm{D}$ were placed with their dams, and finally in the following year the birds in Flocks $E$ and $F$ were placed together. After being placed together these three lots of sisters were fed on a similar ration.

The strain of Leghorns used was originally procured from H. J. Blanchard, formerly of Groton, N. Y. Later, males from D. W. Young were used, and in 1919 females from D. B. McNeil of Moorefield, W. Va. were added to the flock. Practically no effort had been made to increase the egg production of this strain by systematic breeding prior to the beginning of this experiment.

\section{FEEDING THE LAYERS}

Dry mash consisting of two parts of corn meal and one part each of wheat bran, wheat middlings, and meat scrap was fed in hoppers; and the whole grain consisted of two parts each of corn and wheat, and one part of oats. A moderate amount of semisolid buttermilk also was fed three or four times per week.

\section{WEIGHING THE EGGS AND FOWLS}

The eggs were weighed regularly each morning after the day they were laid. In the beginning a chemical balance was used. Later a special chainomatic balance was employed. With this bal-

(6) Poultry Science Vol. 1, No. 6, pp. 177-185.

(7) W. Va. Agr. Exp. Station Bulletin 179. 
ance, 70 or 80 eggs per hour could be weighed. The readings were recorded to the .01 part of a gram.

Each bird was weighed at the beginning of each calendar month and the weight recorded to the .1 of a pound.

\section{WEIGHT OF EGGS AS CORRELATED WITH THE AGE OF PULLET WHEN BEGINNING TO LAY}

From a practical standpoint it is desirable to have the pullets begin to lay while reasonably young, and it is important to know what influence early sexual development or precociousness in fowls has upon the size of the eggs laid.

Table 1 shows the number of females in each flock, the mean age in days of the females in each flock when the first egg was laid, and the standard deviation.

\section{TABLE I.-Age of Pullets When Beginning to Lay.}

\begin{tabular}{c|c|c|c}
\hline \hline Flock & $\begin{array}{c}\text { Number of } \\
\text { Females }\end{array}$ & $\begin{array}{c}\text { Mean Age When First } \\
\text { Egg Was Laid }\end{array}$ & Standard Deviation \\
\cline { 2 - 4 } A & 24 & $178.3 \pm 1.3$ & $9.1 \pm .88$ \\
B & 24 & $198.1 \pm 1.7$ & $12.4 \pm 1.21$ \\
C & 20 & $196.9 \pm 3.3$ & $22.1 \pm 2.35$ \\
D & 19 & $226.3 \pm 1.9$ & $12.7 \pm 1.38$ \\
E & 46 & $209.9 \pm 1.9$ & $18.9 \pm 1.32$ \\
F & 47 & $247.9 \pm 1.7$ & $17.7 \pm 1.23$ \\
\hline
\end{tabular}

It is evident that the fowls which received the liberal supply of protein of animal origin while young (A, C, and E) began to lay from 20 to 30 days younger than did their respective sisters.

It is also apparent from the table that there was a progressive increase in the age of laying the first egg, the average for flocks A and $B$ being 188.2 \pm 1.0 ; for $C$ and $D 211.6 \pm 1.9$; and for $E$ and $F$ $228.9 \pm 1.3$. The reason for the greater age of $C$ and $D$ as compared to $A$, and $B$ can be understood, for when the most precocious pullet in flock C began to lay the fowls in flocks C and D were placed in the same house with their dams and were somewhat handicapped by being with older fowls, which might account for their slower development. Additional evidence to support this view is given by the standard deviation which in the case of Flock $C$ is more than twice as great as in Flock $\mathrm{A}$, but there is no apparent reason why 
flocks $\mathrm{E}$ and $\mathrm{F}$ should have developed so slowly. It is possible that whole milk as the entire source of protein of animal origin may have brought about slow maturity. It is evident from the figures here presented that the rate at which pullets mature can be greatly influenced by the ration which they receive during their early growth, and possibly also by their later surroundings. Here lies a fertile field for further investigation, as the factors bringing about and regulating the rate of sexual development in fowls have been studied but little.

\section{WEIGHT OF THE FIRST TEN EGGS LAID}

In calculating the correlations, the average weight of the first ten eggs laid by each pullet has been used.

TABLE II.-Mean Weight in Grams of the First Ten Eggs Laid by Each Pullet for the Six Flocks Together with the Standard Deviation.

\begin{tabular}{c|c|c|c}
\hline Flock & $\begin{array}{c}\text { Number of } \\
\text { Females }\end{array}$ & $\begin{array}{c}\text { Mean Weight of First } \\
\text { Ten Eggs Laid }\end{array}$ & Standard Deviation \\
\cline { 1 - 1 } $\mathrm{A}$ & 24 & $44.20 \pm .30$ & $2.2 \pm .20$ \\
$\mathrm{~B}$ & 24 & $46.51 \pm .43$ & $3.1 \pm .30$ \\
$\mathrm{C}$ & 20 & $45.50 \pm .45$ & $3.0 \pm .32$ \\
$\mathrm{D}$ & 19 & $46.57 \pm .45$ & $2.9 \pm .32$ \\
$\mathrm{E}$ & 46 & $47.02 \pm .29$ & $2.9 \pm .20$ \\
$\mathrm{~F}$ & 47 & $49.86 \pm .28$ & $2.9 \pm .20$ \\
\hline
\end{tabular}

Table II shows that the eggs laid by the fowls in flocks A, C, and $\mathrm{E}$ were smaller than those laid by their respective sisters, who were older on the average when they began to lay. In case of flocks $\mathrm{C}$ and $\mathrm{D}$, the difference is not statistically significant.

The coefficients of correlation, age in days of each pullet when first eggs was laid subjective, average weight of first ten eggs laid by each pullet relative, are shown in Table III.

In calculating these correlations the method described by Dr. Frank M. Phillips in Monthly Weather Review (March, 1922) has been used. 
TABLE III.-Correlation Between Age when Laying First Egg and Average Weight of First Ten Eggs Laid.

\begin{tabular}{c|c|ccc}
\hline \hline Flock & No. of Fowls & Coeffieient of Correlation \\
\hline $\mathrm{A}$ & -24 & $\mathrm{r}= \pm .49 \pm .10$ \\
$\mathrm{~B}$ & 24 & $\mathrm{r}= \pm .58 \pm .08$ \\
$\mathrm{C}$ & 20 & $\mathrm{r}= \pm .61 \pm \pm .09$ \\
$\mathrm{D}$ & 19 & $\mathrm{r}= \pm .07 \pm .15$ \\
$\mathrm{E}$ & 46 & $\mathrm{r}= \pm .68 \pm .05$ \\
$\mathrm{~F}$ & 47 & $\mathrm{r}= \pm .34 \pm .08$ \\
\hline
\end{tabular}

In all cases the correlation is positive and in each flock, with the exception of $\mathrm{D}$, the correlation is significant and when taken in connection with the mean age and the mean egg weight for the different flocks the evidence seems conclusive that the older the females before beginning to lay, the heavier are the first eggs laid.

\section{MEAN EGG WEIGHT FOR THE YEAR}

Table IV gives the mean egg weight for flocks A, B, C, and D for the pullet year ending November 30, together with the standard deviations. In calculating the mean egg weight for these flocks the average egg weight for each pullet was determined and the mean for the flock based thereon.

TABLE IV.-Mean Weight of Eggs and Standard Deviation for the Pullet Year.

\begin{tabular}{c|c|c|c}
\hline \multirow{2}{*}{ Flock } & No. Females & $\begin{array}{c}\text { Mean Ggin Weight for } \\
\text { Pullet Year }\end{array}$ & Standard Deviation \\
& & $50.22 \pm .26$ & $1.9 \pm .18$ \\
$\mathrm{~B}$ & 24 & $50.45 \pm .37$ & $2.7 \pm .26$ \\
$\mathrm{C}$ & 24 & $51.29 \pm .30$ & $2.0 \pm .21$ \\
$\mathrm{D}$ & 10 & $50.11 \pm .40$ & $2.6 \pm .28$ \\
\hline
\end{tabular}

By a comparison of tables II and IV the increase in the mean weight of the eggs for the year over the mean weight for the first ten eggs is shown in Table $\mathrm{V}$. 
TABLE V.-Difference Between Mean Weight of First Ten Eggs Laid and the Mean Weight for the Year.

\begin{tabular}{c|c|c}
\hline Flock & No. Females & Grams \\
\cline { 1 - 1 } A & & $6.02 \pm .39$ \\
$\mathrm{~B}$ & 24 & $3.94 \pm .56$ \\
$\mathrm{C}$ & 24 & $5.79 \pm .54$ \\
$\mathrm{D}$ & 19 & $3.54 \pm .60$ \\
\hline
\end{tabular}

Remembering that flocks $\mathrm{A}$ and $\mathrm{C}$ began to lay at a younger age than did $\mathrm{B}$ and $\mathrm{D}$, we find it of interest to observe that the mean weight of the eggs for these two flocks for the year increased over the mean weight for the first ten eggs, about 2 grams more per egg than was the case with $B$ and $D$. The mean weight of the eggs for the year for flocks $A$ and $C$ was about 13 percent greater than the mean for the first ten eggs, while with flocks B and D this increase was only about 8 percent.

The correlations for flocks A, B, C, and D between age in days when laying first egg subjective, and mean egg weight for each pullet for the pullet year relative are as follows:

TABLE VI.-Correlations Between Age in Days When Laying: the First Egg and the Mean Egg Weight for the Pullet Year.

\begin{tabular}{c|c|c}
\hline Flock & Vo. Females & Coefficient of Correlation \\
\hline A & 24 & $\mathrm{r}= \pm .04 \pm .14$ \\
$\mathrm{~B}$ & $\mathrm{r}= \pm .33 \pm .12$ \\
$\mathrm{C}$ & $\mathrm{r}= \pm .04 \pm .15$ \\
$\mathrm{D}$ & $\mathbf{r}=-.03 \pm \pm .15$ \\
\hline
\end{tabular}

In no case are these correlations significant and it would seem that the characteristic mean egg weight for each individual had no relationship to the age of the fowl when beginning to lay.

CORRELATION BETWEEN MEAN WEIGHT OF FIRST TEN

EGGS LAID AND MEAN WEIGHT OF EGGS LAID

BY EACH BIRD DURING PULLET YEAR

As flocks $A$ and $C$ had been fed similarly while young as had also flocks $\mathrm{B}$ and $\mathrm{D}$, in the following discussion the data regarding $\mathrm{A}$ and $\mathrm{C}$ are brought together and treated as though the two lots of fowls were one flock, and similarly with flocks B and D. 
Table VII shows the mean egg weight and the standard deviations for the first ten eggs for the pullet year for the flocks $A$ and $C$, and $\mathrm{B}$ and $\mathrm{D}$.

TABLE VII.-Mean Weight of First Ten Eggs Laid and Mean| Weight of Eggs for the Pullet Year, Together With' the Standard Deviations for Flocks $A$ and $C$ and B and $\mathrm{D}$.

\begin{tabular}{|c|c|c|c|c|c|}
\hline lock & No, of Fowls & $\begin{array}{l}\text { Mean } \\
\text { Weight First } \\
\text { Ten Eggs }\end{array}$ & $\begin{array}{l}\text { Standard } \\
\text { Deviation }\end{array}$ & $\begin{array}{l}\text { Mean Egg } \\
\text { wt. Pullet } \\
\text { Year }\end{array}$ & $\begin{array}{l}\text { Standard } \\
\text { Deviation }\end{array}$ \\
\hline & 44 & $44.79 \pm .29$ & $2.7 \pm .19$ & $50.70 \pm .22$ & $2.2 \pm .16$ \\
\hline B, D & 43 & $46.54 \pm .30$ & $2.9 \pm .21$ & $50.30 \pm .28$ & $2.7 \pm .20$ \\
\hline
\end{tabular}

The correlations between mean egg weight of the first ten eggs which were laid subjective, and mean egg weight of the eggs laid by each bird during the pullet year relative are shown below.

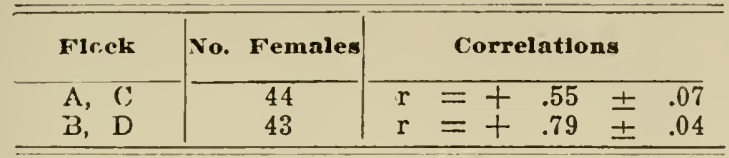

The correlations are positive and significant and show that the characteristic egg weight of the first few eggs laid by a pullet tends to persist throughout the year.

\section{CORRELATION BETWEEN NUMBER OF EGGS LAID AND THEIR WEIGHT}

Among many poultrymen the belief prevails that the heavy layers lay slightly smaller eggs than the average for the flock. If this be true, then it might be possible that in breeding and selecting fowls in order to obtain better layers this result might be accomplished without increasing the total weight of the eggs laid by that strain. Under these circumstances breeding for increased numbers of eggs might result in little if any economic advantage.

Table VIII shows the mean number and mean weight of eggs laid and the standard deviations for flocks $A, B, C$, and D for the pullet year, and for flocks $A$ and $B$ for the second year. In all cases the end of the laying year was taken as November 30 . 
TABLE VIII.-Mean Number and Weight of Eggs Together with the Standard Deviation for Flocks A, B, C, and D.

\begin{tabular}{|c|c|c|c|c|c|c|c|}
\hline Flock & No. of Fowls & Mean & $\begin{array}{l}\text { No. } \\
\text { gss }\end{array}$ & of & $\begin{array}{c}\text { Standard } \\
\text { Deviations }\end{array}$ & $\mid \begin{array}{l}\text { Mean wVt. of } \\
\text { Eggs (Grams) }\end{array}$ & $\begin{array}{c}\text { Standard } \\
\text { Deviations }\end{array}$ \\
\hline $\mathbf{A}$ & 24 & 148.08 & \pm & 4.3 & $31.2 \pm 3.0$ & $50.22 \pm .26$ & $1.9 \pm .18$ \\
\hline B & 24 & 12. & \pm & 4.8 & $35.3 \mp 3.4$ & $50.45 \pm .37$ & $2.7 \pm .26$ \\
\hline C & 20 & 141.60 & \pm & 4.5 & $30.0 \pm 3.2$ & $51.29 \pm .30$ & $2.0 \pm .21$ \\
\hline $\mathrm{D}$ & 20 & 122.75 & \pm & 4.9 & $\begin{array}{c}32.3 \overline{2 n d}_{\text {Year }} \\
\text { 2nd }\end{array}$ & $50.13 \pm .39$ & $2.6 \pm .27$ \\
\hline $\mathbf{A}$ & 23 & 15 & \pm & 3.7 & $26.1 \pm 2.6$ & $55.87 \pm .37$ & $2.6 \pm .26$ \\
\hline B & 21 & 150.10 & \pm & 2.9 & $20.0 \pm 2.1$ & $55.94 \pm .48$ & $3.3 \pm .34$ \\
\hline
\end{tabular}

The table shows that the standard deviations, both for number and weight of eggs, are greater in the case of the fowls poorly fed while young, with an exception in the second year of the deviation for the number of eggs. The fowls well fed while young laid better during the pullet year than did their respective sisters.

The correlations, number of eggs laid by each bird subjective, and mean egg weight for the year relative, are shown in Table IX.

\section{TABLE IX.-Correlations Between Number of Eggs Laid and Mean Weight of Eggs.}

\begin{tabular}{|c|c|c|c|c|c|c|}
\hline \multirow{3}{*}{$\begin{array}{c}\text { Flock } \\
\begin{array}{c}\mathrm{A} \\
\mathrm{B}\end{array}\end{array}$} & No. Females & \multicolumn{5}{|c|}{ Correlations } \\
\hline & 24 & $\mathrm{r}$ & $=t$ & .41 & \pm & .11 \\
\hline & 24 & $\mathrm{r}$ & $=+$ & .26 & \pm & .13 \\
\hline C & 20 & $\mathbf{r}$ & $=+$ & .19 & \pm & .14 \\
\hline \multirow[t]{2}{*}{ D } & 20 & $\mathrm{r}$ & $=+$ & .22 & $\overrightarrow{ \pm}$ & .14 \\
\hline & 2nd Year & & & & & \\
\hline A & 23 & $\mathbf{r}$ & $=+$ & .24 & \pm & .13 \\
\hline B & 21 & $\mathrm{r}$ & $=+$ & .03 & \pm & .15 \\
\hline
\end{tabular}

The correlations are not significant, with possibly an exception in the case of Flock A, for the pullet year, yet they are all positive and hence the data do not lend color to the belief that the heavy layers tend to lay smaller eggs than the average of the flock. On account of the importance of the subject, additional data are being accumulated at the West Virginia Experiment Station.

EGG PRODUCTION AND WEIGHT OF FOWLS AS RELATED TO THE SEASON OF THE YEAR

Egg production, it is well known, is not distributed uniformly throughout the year, but is usually greatest during the spring months. 
Figure 1 shows graphically the mean monthly weight of the fowls in flocks A, B, C, and D for the pullet year and for flocks A and B for the yearling year. Figure 2 shows the mean number of eggs laid by these fowls during each month of the year and Fgure 3 shows the mean weight of the eggs for each month.

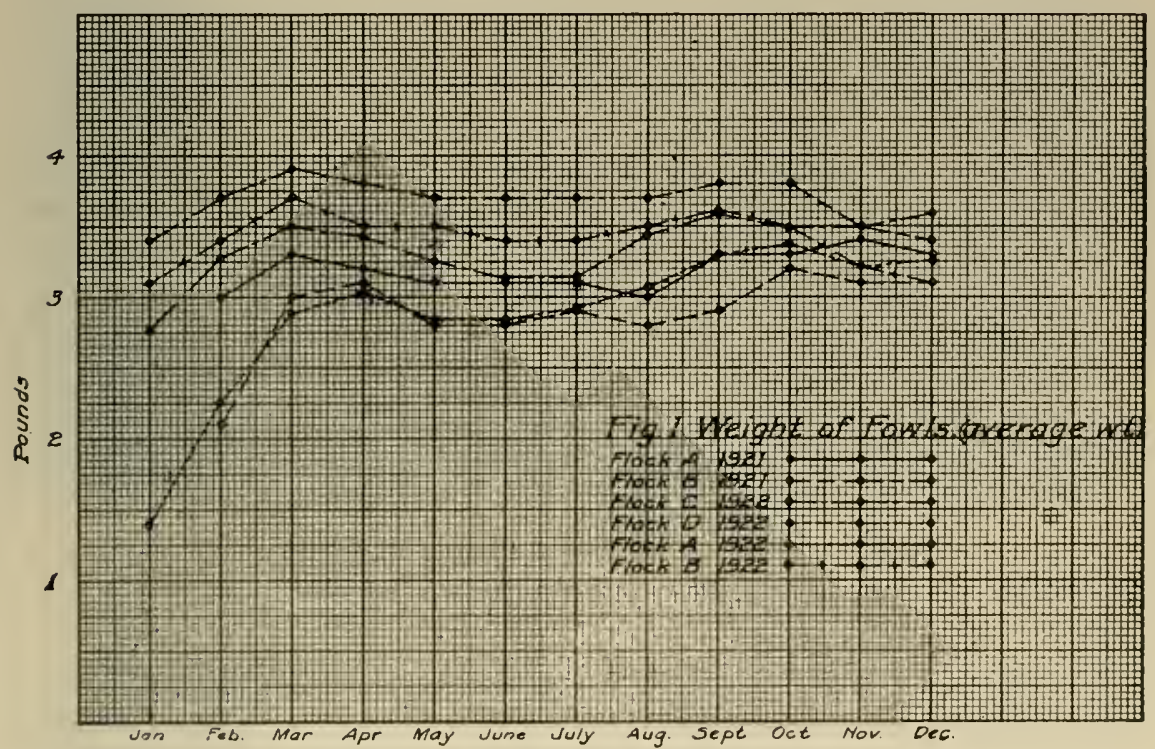

Fig. 1.-Average Weight of Fowls.

From Figure 1 it is evident that the maximum weight of both pullets and yearling hens was reached about March 1 . There was a slight decrease during the summer, with an increase beginning about August 1 and extending to September or ()ctoler, then a drop to Decemlier. 


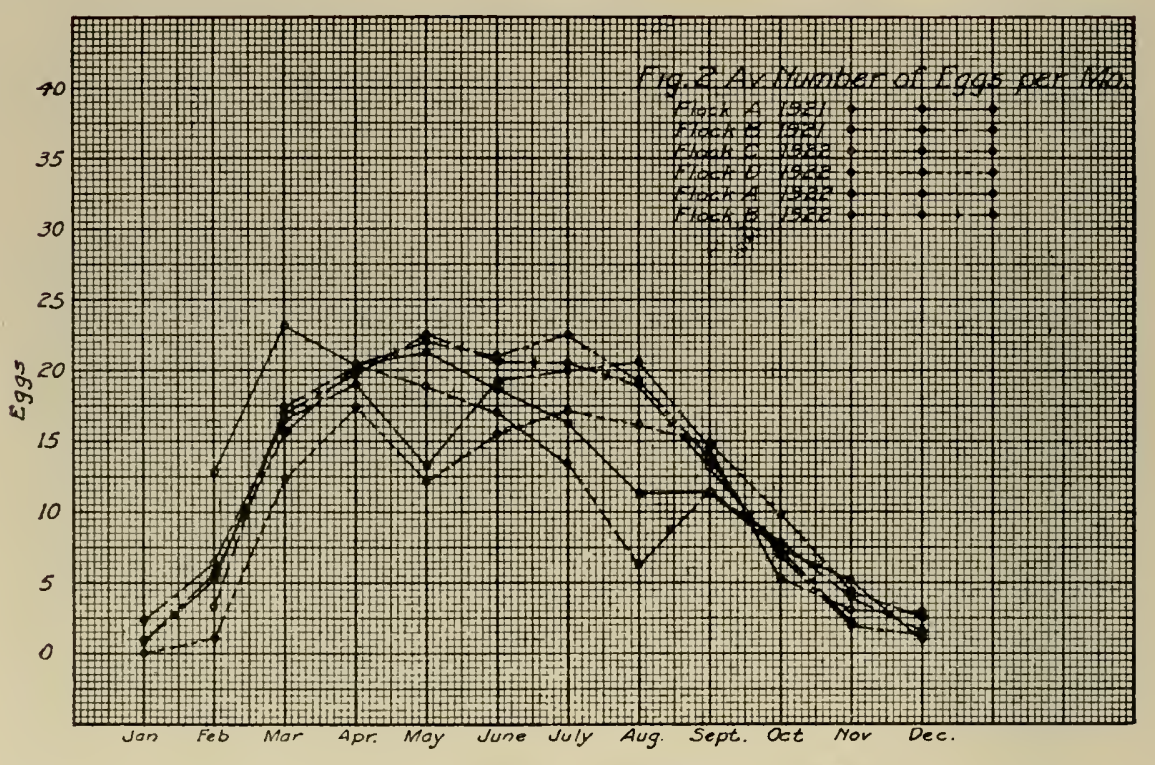

Fig. 2.-Average Number of Eggs Per Month.

Figure 2 shows that there was a rapid increase in egg production beginning in February, the maximum for the year being generally reached in April or May and from this maximum there was a more or less regular decrease toward the end of the laying season. 


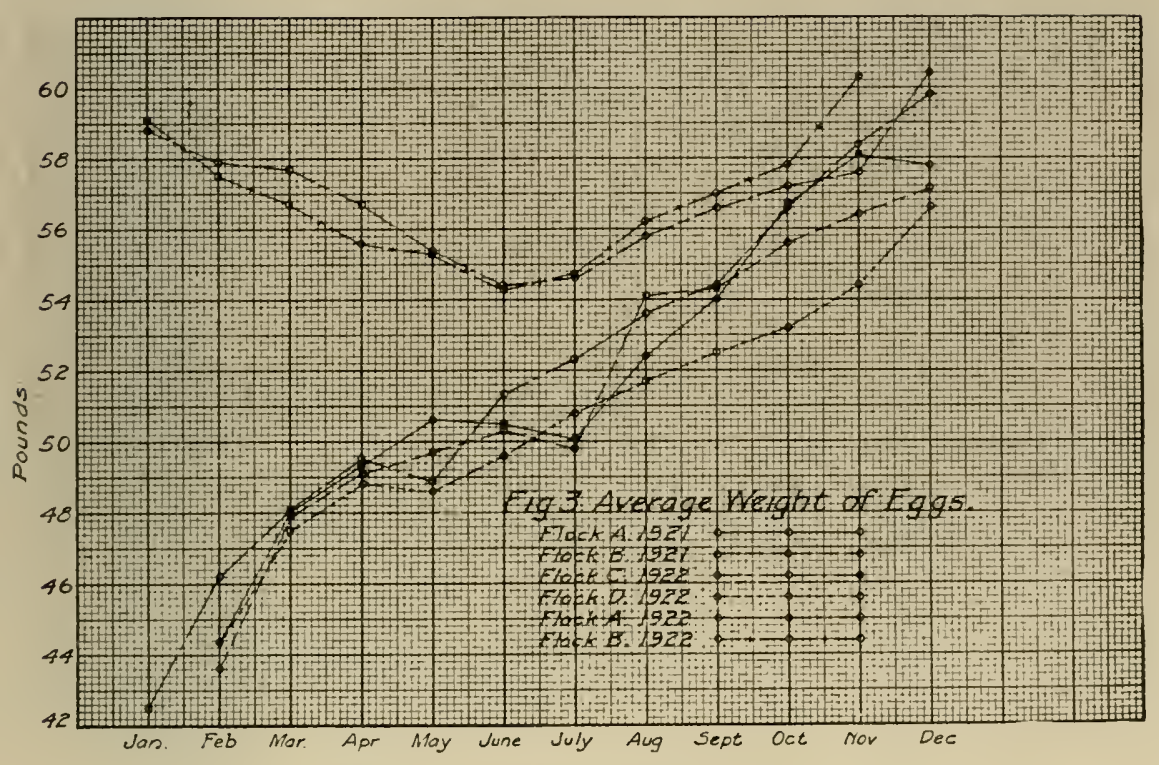

Fig. 3,-Average weight of Eggs.

As shown by Figure 3 there was a reasonably regular increase in the weight of the pullet eggs from the beginning to the end of the first laying year. In this connection it should be remembered that all of these pullets were late hatched and did not begin to lay until January or February. In the case of the yearling hens, the heaviest eggs were laid in winter, and the lightest ones in June and July.

\section{CORRELATION BETWEEN THE AVERAGE WEIGHT OF THE EGGS AND THE NUMBER LAID DURING ANY MONTH OF THE YEAR}

Are the eggs as large when hens are laying freely as when they are not? The answer to this question may have some bearing upon the selection of eggs for hatching, since the large egg hatches out the large chick.

Table $\mathrm{X}$ shows the average number and average weight of eggs laid per month for flocks A, B, C, and D for the pullet year and for $A$ and $B$ for the yearling year. 
\&

(1)

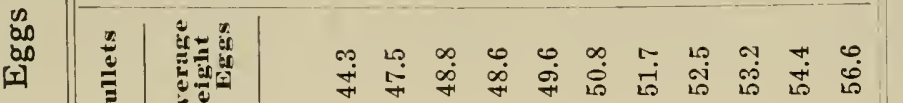

07

$\Psi$ 莕

$\circ$

$\underset{\partial}{\Rightarrow} \frac{0}{\partial}$

$\cdot \stackrel{2}{ \pm}$

$\geqslant .0$

$\stackrel{-}{\rightleftarrows}$

$\Xi \stackrel{巳}{\ddagger}$

峞

(3)

要

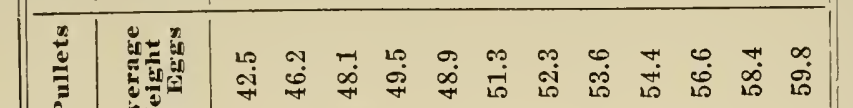

(1)

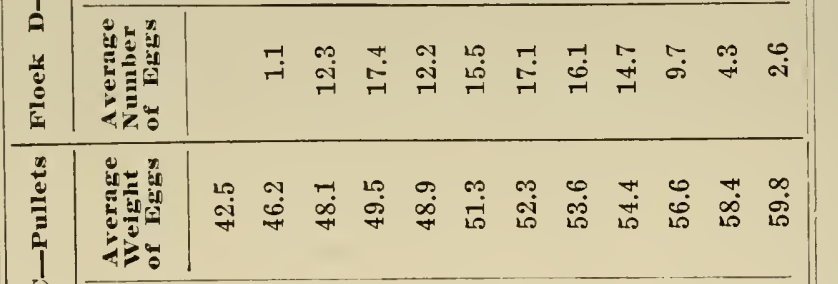

崩

-

$\Xi \infty$

芠

总>

$5 \%$

는

|

㟧

$\sum_{0}^{\infty} \overbrace{0}^{\infty} \stackrel{\infty}{\rightleftarrows}$

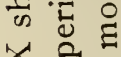

|

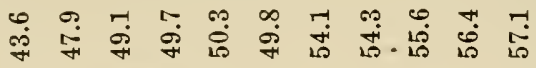

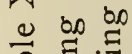

ก.

政 疍

㔖导

三山。

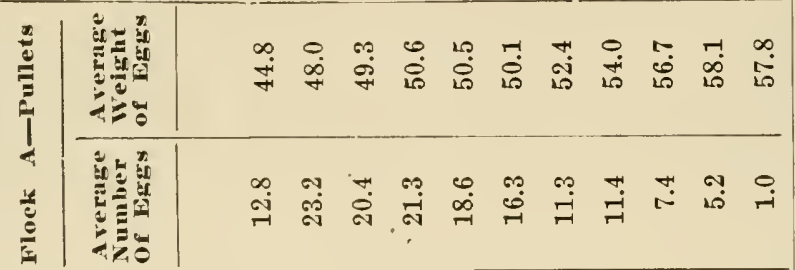

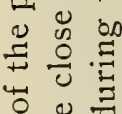

(

感

ชิ $\circ$

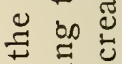

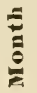

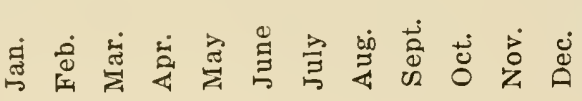
$\underline{1}$ E. - 
TABLE XI.-Correlations Between the Mean Number of Eggs Laid per Month, and the Mean Monthly Weight of Eggs.

\begin{tabular}{|c|c|c|c|c|c|c|}
\hline \multirow{2}{*}{$\frac{\text { Flock }}{\text { A-Pullets }}$} & No. of Females & \multicolumn{5}{|c|}{ Correlations } \\
\hline & 24 & $\mathrm{r}$ & $=-$ & .79 & \pm & .08 \\
\hline B-Pullets & 24 & $r$ & $=-$ & .44 & \pm & .16 \\
\hline C-Pullets & 20 & $\mathrm{r}$ & $=\ldots$ & .14 & \pm & .19 \\
\hline D-Pullets & 20 & $r$ & $=-$ & .13 & \pm & .17 \\
\hline A-Yearlings & 23 & $\mathrm{r}$ & $=-$ & .59 & \pm & .13 \\
\hline $\mathrm{B}-$ Yearlings & 21 & $\mathrm{r}$ & $=-$ & .88 & \pm & .05 \\
\hline
\end{tabular}

All of the coefficients are negative and in Flock A (pullets) and flocks $A$ and $B$ (yearlings) the correlations are apparently significant. We may conclude that in general the greater the number of eggs laid during any month, the smaller the eggs tend to become.

\section{RELATIONSHIP BETWEEN BODY WEIGHT AND EGG WEIGHT}

In the correlations reported in Table XII the mean weight of the fowls at the beginning of each calendar month is subjective and the mean egg weight of all eggs laid in the trap nests for the month is relative.

TABLE XII.-Correlations Between Weight of Fowls and Mean Monthly Egg Weight.

\begin{tabular}{|c|c|c|c|c|c|c|}
\hline \multirow{2}{*}{$\frac{\text { Flock }}{\text { A-Pullets }}$} & No. of Females & \multicolumn{5}{|c|}{ Correlation } \\
\hline & 24 & $r$ & $=+$ & .65 & \pm & .12 \\
\hline B-Pullets & 24 & $\mathrm{r}$ & $=+$ & .72 & \pm & .10 \\
\hline C-Pullets & 20 & $\mathrm{r}$ & $=+$ & .71 & $\mp$ & .10 \\
\hline $\mathrm{D}$-Pullets & 20 & $r$ & $=+$ & .87 & \pm & .10 \\
\hline A-Yearlings & 23 & $r$ & $=+$ & .47 & $\overline{ \pm}$ & .15 \\
\hline $\mathrm{B}$-Yearlings & 21 & r & $=-$ & .37 & \pm & .18 \\
\hline
\end{tabular}

With all four pullet flocks the correlation is positive and significant showing that the increase in the weight of the body went hand in hand with the increase in the weight of the egg. This relationship, however, does not seem to hold good with the yearling hens. 


\section{CONCLUSIONS}

1.-Chickens which received a liberal amount of protein of animal origin while young developed more rapidly and began to lay at a younger age than did their sisters whose supply of protein of animal origin was restricted.

2.-The younger the pullets when beginning to lay, the smaller were the first eggs laid.

3.-The younger the pullets when beginning to lay, the greater was the percentage increase in the weight of the eggs.

4.- There was no correlation between early maturity in fowls and mean egg weight for the pullet year.

5.-An improperly balanced ration fed to growing chickens increased variability with respect both to the number and mean weight of eggs laid during the pullet year.

6.-The characteristic egg weight of the first few eggs laid by a pullet tended to persist throughout the pullet year.

7.- The data indicated that the heavy layers laid eggs that were at least as heavy as the average for the breed or strain.

8.-Pullets and laying hens were heaviest in the spring.

9.-The maximum egg production was reached in April or May.

10.-Pullet eggs increased in weight from the beginning to the end of the first laying period.

11.-With yearling hens the eggs lightest in weight were laid during the summer months.

12.-The more eggs laid during any particular period, the smaller they tended to become for that period.

13. - With pullest the mean weight of the eggs increased concurrently with the increase in the weight of the birds. 

